University of Nebraska - Lincoln

DigitalCommons@University of Nebraska - Lincoln

Agronomy \& Horticulture -- Faculty Publications

Agronomy and Horticulture Department

$9-1968$

\title{
Water-soluble Factors in Melilotus Leaves Which Influence Feeding by the Sweetclover Weevil
}

\author{
W. R. Akeson \\ University of Nebraska-Lincoln \\ Francis A. Haskins \\ University of Nebraska-Lincoln, fhaskins@neb.rr.com \\ Herman J. Gorz \\ United States Department of Agriculture \\ G. R. Manglitz \\ United States Department of Agriculture
}

Follow this and additional works at: https://digitalcommons.unl.edu/agronomyfacpub

Part of the Plant Sciences Commons

Akeson, W. R.; Haskins, Francis A.; Gorz, Herman J.; and Manglitz, G. R., "Water-soluble Factors in Melilotus Leaves Which Influence Feeding by the Sweetclover Weevil" (1968). Agronomy \& Horticulture -Faculty Publications. 228.

https://digitalcommons.unl.edu/agronomyfacpub/228

This Article is brought to you for free and open access by the Agronomy and Horticulture Department at DigitalCommons@University of Nebraska - Lincoln. It has been accepted for inclusion in Agronomy \& Horticulture -Faculty Publications by an authorized administrator of DigitalCommons@University of Nebraska - Lincoln. 


\title{
Water-soluble Factors in Melilotus Leaves Which Influence Feeding by the Sweetclover Weevil ${ }^{1}$
}

\author{
W. R. Akeson, F. A. Haskins, H. J. Gorz, and G. R. Manglitz ${ }^{2}$
}

\section{ABSTRACT}

One factor which stimulates feeding and two factors which deter feeding by the adult sweetclover weevil have been separated by preparative paper chromatography of hot water extracts of Melilotus leaves. The factors were detected with a bioassay which measures feeding by adult wecvils on sweetclover root disks impregnated with the extract or fraction being tested. A feeding stimulant (Stimulant $A$ ) and a feeding deterrent (Deterrent $A$ ) were found in both the resistant species, $M$. infesta, and a susceptible species, $M$. officinalis, in approximately equal amounts. A second feeding deterrent (Deterrent B) was found only in extracts from $M$. infesta. All available cvidence suggests that Deterrent $B$ is the factor primarily responsible for the resistance of $M$. infesta to the swecetclover weevil.

Additional key words: Sitona cylindricollis, sweetclover weevil, Melilotus infesta, Melilotus officinalis, paper chromatography, bioassay, feeding stimulant, feeding deterrent.

A MONG nineteen Melilotus species tested by Manglitz and Gorz (5), only $M$. infesta Guss. displayed appreciable resistance to feeding by the adult sweetclover weevil, Sitona cylindricollis (Fahraeus). This resistance was confirmed by Gross and Stevenson (4) and Radcliffe and Holdaway $(6,7)$.

As a first step in studying the chemical nature of the weevil resistance of $M$. infesta, Akeson et al. (2) developed a bioassay for the detection of factors

\footnotetext{
${ }^{1}$ A cooperative investigation between the Nebraska Agricultural Experiment Station, University of Nebraska, and the Entomology Research Division and Crops Research Division. Agr. Res. Serv., USDA, supported in part by ARS Grant No. 12-14-100-8027(33). Contribution No. 294 of Department of Entomology, University of Nebraska. Pubfished with approval of the Director as Paper No. 2273. Journal Series, Neb. Agr. Exp. Sta. Received March 15, 1968.

${ }^{2}$ Assistant Professor and Professor of Agronomy, Univ. of Nebraska; Research Geneticist, Crops Research Division, and Research Entomologist, Entomology Research Division, ARS, USDA, respectively, Lincoln, Neb. 68503. The technical assistance of Henry J. Stevens, Agr. Res. Tech., Entomology Research Division, ARS, USDA; and Gary L. Beland, Grad. Res. Asst., Dept. of Entomology, Univ. of Nebraska, is gratefully acknowledged.
}

which influence feeding by the adult weevil. The bioassay employs solvent-extracted disks of sweetclover root tissue. Disks are impregnated with the plant extracts to be tested and offered to adult weevils for feeding. After the feeding period, reaction of the weevils is determined by measuring the disk area consumed.

Initially the bioassay was used to compare the feeding response of the weevil to the chloroform and water-methanol phases of water-methanol-chloroform extracts of leaves representing $M$. infesta and a weevil-susceptible species, $M$. officinalis (L.) Lam. (2). Feeding was extensive on root disks treated with the chloroform phase from cither species; thus, both species apparently contain a hydrophobic substance or substances with feeding stimulant activity. The two species differed greatly, however, with respect to the degree of feeding stimulated by the watermethanol phase. Disks treated with this phase from $M$. officinalis were extensively consumed, whereas only a small amount of feeding occurred on disks treated with the corresponding phase from $M$. infesta. These observations indicate that the resistance of $M$. infesta is due to the absence of a hydrophilic feeding stimulant, or to some combination of deterrent and stimulant activities different from that existing in $M$. officinalis. On the basis of the initial observations a choice of the alternatives could not be made.

A chromatographic fractionation of the hydrophilic weevil-influencing constituents of $M$. officinalis and $M$. infesta leaves has now been accomplished. The chromatographic purification of a feeding stimulant, designated Stimulant $A$, from $M$. officinalis extracts has been described elsewhere (1). The further evaluation of Stimulant $A$ and the chromatographic purification and subsequent evaluation of two feeding deterrents, designated Deterrents $A$ and $B$, are described in the present report. As used in this paper and as defined by Beck (3), a feeding stimulant refers to a stimulus tending to promote continuous feeding, while a leeding deterrent is a stimulus 
preventing continuous feeding or hastening the termination of feeding.

\section{MATERIALS AND METHODS}

In these studies the weevil-resistant $M$. infesta was represented by Nebraska Strain $\mathbf{M} 70^{3}$. The weevil-susceptible species of Melilotus were represented by $M$. officinalis var. 'Goldtop' (F.C. 38,923). All plants for extraction were grown in the greenhouse. Sweetclover root disks for use in the bioassay were obtained from field-grown roots of $M$. alba Desr. var. 'Evergreen.' 'The preparation of these root disks, and procedures used in the bioassay were described earlier (2).

Preliminary trials indicated that hot water extracts of $M$. infesta and $M$. officinalis leaves elicited the same feeding responses as the water-methanol phase of water-methanol-chloroform extracts. Extraction with hot water as described by Akeson et al. (1) is operationally simple, and provides for the rapid inactivation of enzymes which otherwise might alter the active compounds. Therefore, hot water extraction was used routinely in this work. Briefly, the extraction procedure was as follows: Freshly harvested young leaves were weighed, washed with distilled water, dropped into boiling water $(10 \mathrm{ml} / \mathrm{g}$ of fresh tissue), and boiled for 5 minutes. The hot mixture was homogenized for 2 minutes in a blender and then boiled for an additional 5 minutes. The homogenate was cooled to room temperature and centrifuged at $2400 \times \mathrm{g}$ for 30 minutes. The supernatant liquid was flash evaporated at $40 \mathrm{C}$ to a volume of $5 \mathrm{ml} / \mathrm{g}$ of original dry tissuc and stored at $-20 \mathrm{C}$. Calculations of dry matter percentage were based on representative leaf samples dricd for 6 hours at $110 \mathrm{C}$.

Chromatography of hot water extracts for the detection of active factors and determination of $\mathbf{R}_{\mathbf{F}}$ values were accomplished essentially as described by $A$ keson et al. (I). Active factors were partially purified by first chromatographing crude extracts on $181 / 2 \times 281 / 2 \cdot \mathrm{cm}$ sheets of Whatman No. 3 filter paper with an ascending solvent consisting of isopropyl alcohol, ammonium hydroxide, and water $(8: 1: 2, \mathrm{v} / \mathrm{v} / \mathrm{v})$. Development of the chromatograms was continued until the solvent had reached a height of $15 \mathrm{~cm}$ above the base line. After air-drying, horizontal sections corresponding to the three active factors were cut from the appropriate portions of the chromatogram. The three bands were eluted with water, and the cluates were re-chromatographed on separate chromatograms which were developed with a solvent consisting of isopropyl alcohol, acetic acid, and water $(8: 1: 3, v / v / v)$. Bands corresponding to the three active factors again were eluted with water to give partially purified fractions. For use in the tests to be described, active fractions were diluted such that $1 \mathrm{ml}$ of eluate represented $0.16 \mathrm{~g}$ of dry leaf tissue.

The bioassay procedure of Akeson et al. $(1,2)$ was used in testing crude extracts and eluates for stimulant or deterrent activity. Wecvils fed very little on root disks treated with water or non-active fractions; thus, extensive consumption of disks indicated the presence of material(s) with feeding stimulant activity. lecding deterrent activity was detected by mixing equal volumes of Stimulant $A$ eluate and the fraction being tested and subjecting the mixture to bioassay. Detcrrent activity was indicated if an appreciable decrease was observed in the extent of feeding on disks treated with the fraction plus Stimulant $A$ as compared with disks treated with Stimulant $A$ alone or Stimulant A plus non-active eluates.

\section{RESULTS AND DISCUSSION}

$R_{F}$ values for Stimulant $A$ and $B$ in the two chromatographic systems described in the preceding section of this report are listed in Table 1 . Values also are shown for the methanol solvent. Among 10 solvent systems tested, only these three effected satisfactory separation of Stimulant $A$ and Deterrent b. The similarity in chromatographic behavior of Stimulant $A$ and Deterrent $B$ indicates that these two compounds may have similar structures even

\footnotetext{
${ }^{3}$ This strain of $M$. infesta originated in Algeria and is a seed increase from a sample obtained from George Stevenson and Hugo Gross, Canada Dept. of Agriculture, Brandon, Manitoba Canada, as Brandon No. 6l-98.
}

though they have opposite effects on weevil feeding. Furthermore, the relative insensitivity of the chromatographic behavior of these two factors to changes in solvent $\mathrm{pH}$ (compare solvents I and II, 'Iable 1) indicates a probable absence of free ionizable groups in the compounds. The behavior of Deterrent $A$ appears to be influenced by $\mathrm{pH}$, but the effect is not striking. As suggested by the values included in Table 1 and, as further discussed in the remainder of this report, both $M$. officinalis and $M$. infesta appear to contain Stimulant $A$ and Deterrent $A$, but Deterrent B was detected only in $M$. infesta.

Results of the bioassay of crude extracts and partially purified active factors are shown in Table 2. Little feeding occurred on disks treated with distilled water or the crude hot water extract from $M$. infesta leaves, but extensive feeding occurred on disks treated with the $M$. officinalis extract (comparison A). These differences are similar to those observed in the assay of the water-methanol phases of water-methanolchloroform extracts (2).

Stimulant $\Lambda$ appears to be the only feeding stimulant present in hot water extracts of $M$. officinalis leaves (1). Comparison B (Table 2) indicates that $M$. infesta also contains this feeding stimulant, and that it is present in about the same concentration as in $M$. officinalis. Thus, the resistance of $M$. infesta is not caused by the lack of this feeding stimulant.

In feeding assays, comparisons were made of disks treated with Stimulant $A$ alone and Stimulant $A$ combined with an equal volume of the appropriate deterrent fraction. As shown by the results of comparison C (Table 2), both $M$. infesta and $M$. officinalis contain Deterrent $A$ which, under the assay conditions, caused a substantial reduction in weevil feeding. The Deterrent A potency of the $M$. officinalis fraction was about equal to that of the corresponding $M$. infesta fraction; thus, the weevil resistance of $M$. infesta cannot reasonably be ascribed to Deterrent A.

In the Deterrent B assay (comparison D, Table 2) a striking difference between the two Mclilotus species was revealed. Under the assay conditions used, the Deterrent B fraction from $M$. infesta virtually eliminated feeding, while the corresponding $M$. officinalis fraction appeared to have no effect. 'These results indicate that Deterrent $B$ may account for the resistance of $M$. infesta to weevil feeding. This tentative conclusion is supported by comparison $\mathrm{E}$ (Table 2), in which equal volumes of Deterrent $\mathrm{A}$ and Stimulant $A$ were mixed with either Deterrent B from $M$. infesta or the corresponding fraction from $M$. officinalis. The close similarity of these

Table 1. $\mathbf{R}_{F}$ values for Stimulant $A$ and Deterrents $A$ and $B$ separated from hot water extracts of Melilotus leaves. Values are based on ascending chromatography, Whatman No. 3 filter paper, solvent ascent of $15 \mathrm{~cm}$.

\begin{tabular}{|c|c|c|c|c|c|c|}
\hline \multirow[b]{2}{*}{ Factor } & \multirow[b]{2}{*}{ Species } & \multicolumn{5}{|c|}{ Solvent system } \\
\hline & & $\begin{array}{c}\text { I } \\
\text { Isopropyl } \\
\text { alcohol } \\
\text { NH }_{4} \text { OH } \\
\text { Water }\end{array}$ & $\begin{array}{l}8 \\
1 \\
2 \\
\end{array}$ & $\begin{array}{c}\text { II } \\
\text { Isopropyl } \\
\text { alcohol } \\
\text { Acetic acid } \\
\text { Water }\end{array}$ & $\begin{array}{l}8 \\
1 \\
3\end{array}$ & Methanol \\
\hline & & Rf & & $\mathrm{Rf}$ & & $\mathrm{Rf}$ \\
\hline $\begin{array}{l}\text { Stimulant A } \\
\text { Stimulant A }\end{array}$ & M. officinalis & $\begin{array}{l}0.47 \\
0.47\end{array}$ & & $\begin{array}{l}0.45 \\
0.47\end{array}$ & & $\begin{array}{l}0.43 \\
0.43\end{array}$ \\
\hline $\begin{array}{l}\text { Deterrent A } \\
\text { Deterrent A }\end{array}$ & $\begin{array}{l}\text { M. officinalis } \\
\text { M. Infesta }\end{array}$ & $\begin{array}{l}0.08 \\
0.08\end{array}$ & & $\begin{array}{l}0.23 \\
0.23\end{array}$ & & $\begin{array}{l}0.00 \\
0.00\end{array}$ \\
\hline Deterrent $B$ & M. infesta & 0.56 & & 0.55 & & 0.60 \\
\hline
\end{tabular}


Table 2. Feeding by sweetclover weevils on sweetclover root disks treated with crude hot water leaf extract or chromatographically purified fractions of Stimulant $A$, Deterrent A, or Deterrent B. Each comparison was replicated five times. Each replication within a comparison included five disks per treatment. All disks within a replication were mounted in a feeding dish with a population of two weevils per disk.

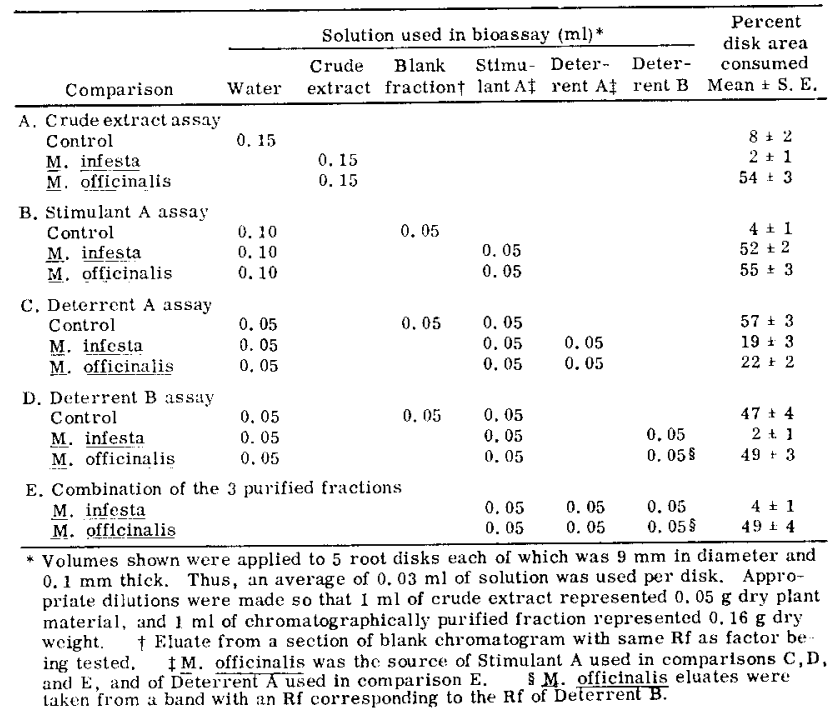

results to those obtained in comparison A strongly suggests that Deterrent $B$ is the principal factor responsible for the wide differences noted with crude extracts of $M$. infesta and $M$. officinalis.

Results of testing various concentrations of Stimulant $A$ and Deterrents $A$ and $B$ are presented in Fig. 1. Clearly the extent of feeding varied with concentration of each of the factors, and the response per unit of active factor was considerably greater at the lower end of the concentration scale than at the upper end. However, the relationship between extent of feeding and concentration of active factors is somewhat variable, and it is not linear for any of the factors. Therefore, the bioassay cannot be used as a highly accurate means of determining concentrations of these substances.

As previously indicated, active fractions were diluted such that equal volumes of fractions represented equal quantities of plant tissue. Assuming no losses cluring extraction and chromatographic purification, an artificial mixture of equal volumes of the Stimulant $A$ and Deterrent $B$ fractions, for example, should contain these two active factors in the same ratio as that existing in intact $M$. infesta leaves. It is interesting to note (Fig. 1) that a 2:I ratio of Deterrent $A$ to Stimulant $A$ was required to reduce feeding to a very low level, whereas a comparably low level was reached by use of a $1: 1$ ratio of Deterrent $B$ and Stimulant A. Either Deterrent B is a much more potent feeding deterrent than Deterrent $A$, or it is present in $M$. infesta leaves at a considerably higher concentration than is Deterrent $A$.

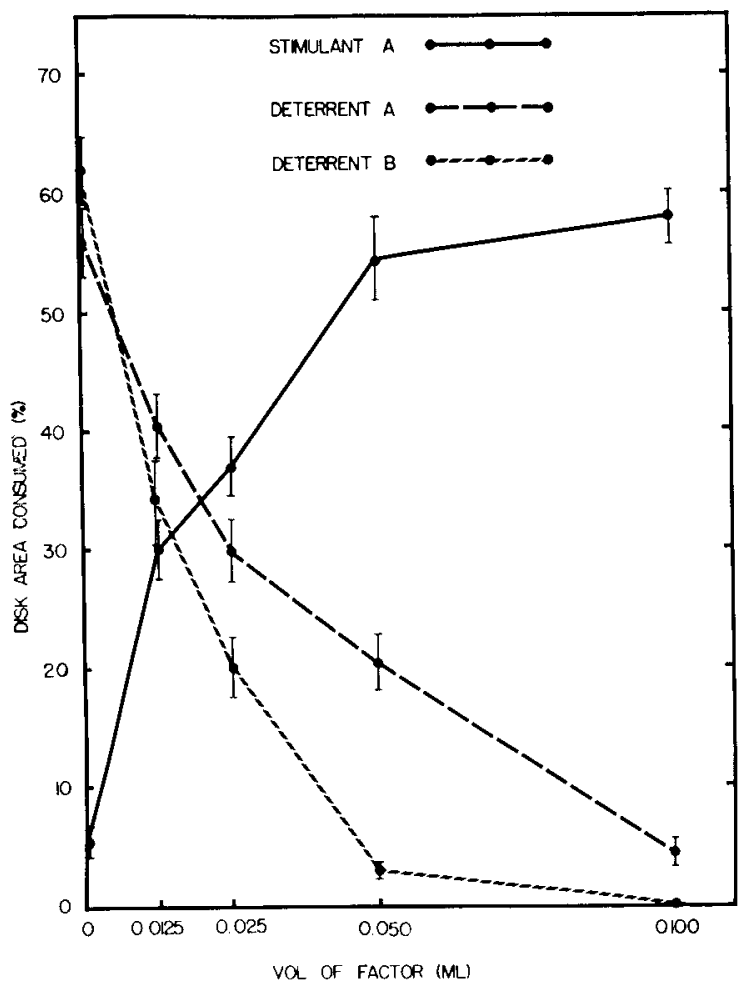

Fig. 1. Effect of concentration of Stimulant $A$, Deterrent A, and Deterrent $B$ on consumption of root disks by the sweet clover weevil. The Stimulant $A$ and Deterrent $A$ fractions used in these tests were obtained from $\boldsymbol{M}$. officinalis while Deterrent $B$ was obtained from $M$. infesta. For the Stimulant A series, each volume shown was diluted to $0.15 \mathrm{ml}$ with water, and five disks were treated with the resulting solution. For the two deterrents, each volume shown was mixed with $0.05 \mathrm{ml}$ of Stimulant $A$ and enough water to bring the total to $0.15 \mathrm{ml}$, and five disks were treated with the resulting solution. Feeding conditions were similar to those described in Table 2. Each point represents the average of 25 disks (five replications of five disks each). Vertical lines above and below each point illustrate the magnitude of the standard error.

\section{LITERATURE CITED}

1. Akeson, W. R., H. J. Gorz, F. A. Haskins, and G. R. Manglitz. 1968 . A water-soluble factor in Melilotus officinalis which stimulates feeding by the adult sweetclover weevil. J. Econ. Entomol. (In press.)

2. Akeson, W. R., G. R. Manglitz, H. J. Gorz, and F. A. Haskins 1967. A bioassay for detecting compounds which stimulate or deter feeding by the sweetclover weevil. J. Econ. Entomol. 60: 1082-1084.

3. Beck, S. D. 1965. Resistance of plants to insects. Ann. Rev Entomol. 10:207-232.

4. Gross, A. T. H., and G. A. Stevenson. 1964. Resistance in Melilotus species to the sweetclover weevil (Sitona cylindri collis). Can. J. Plant Sci. 44:487-488.

5. Manglitz, G. R., and H. J. Gorz. 1964. Host-range studies with the sweetclover weevil and the sweetclover aphid. J Econ. Entomol. 57:683-687.

6. Radcliffe, E. B., and F. G. Holdaway, 1964. Sweetclover re sistance to weevil attack. Minnesota Farm and Home Sci Fall issue 5-7.

7. Radcliffe, E. B., and F. G. Holdaway. 1967. Sweetclover weevil resistance in Melilotus Adans., Medicago L., and Trigonella L. Minnesota Agr. Exp. Sta. Tech. Bull. 255. 26 p. 